\title{
NF-кB Stimulates Inducible Nitric Oxide Synthase to Protect Mouse Hepatocytes From TNF- $\alpha-$ and Fas-Mediated Apoptosis
}

\author{
ETSURO HATANO,*,‡ BRYDON L. BENNETT,§ ANTHONY M. MANNING, $§$ TING QIAN,\| \\ JOHN J. LEMASTERS, and DAVID A. BRENNER*,‡ \\ Departments of *Medicine, ${ }^{\ddagger}$ Biochemistry \& Biophysics, and "Cell Biology \& Anatomy, University of North Carolina at Chapel Hill, Chapel Hill, \\ North Carolina; and §Signal Pharmaceuticals, Inc., San Diego, California
}

Background \& Aims: Hepatocyte apoptosis is induced by tumor necrosis factor $\alpha$ (TNF- $\alpha)$ and Fas ligand. Al-

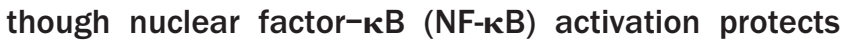
hepatocytes from TNF- $\alpha$-mediated apoptosis, the NF-кB responsive genes that protect hepatocytes are unknown. Our aim was to study the role of NF-kB activation and inducible nitric oxide synthases (iNOSs) in TNF- $\alpha-$ and Fas-mediated apoptosis in hepatocytes. Methods: Primary cultures of hepatocytes from wild-type and iNOS knockout mice were treated with TNF- $\alpha$, the Fas agonistic antibody Jo2, a nitric oxide (NO) donor (S-nitroso-Nacetylpenicillamine), an NO inhibitor ( $N^{\mathrm{G}}$-methyl-L-arginine acetate), and/or adenovirus-expressing NF-кB inhibitors. Results: The ІкB superrepressor and a dominant-negative form of IKB kinase beta (IKK $\beta$ ) inhibited NF- $\kappa$ B binding activity by TNF- $\alpha$ or Jo2 and sensitized hepatocytes to TNF- $\alpha$ - and Jo2-mediated apoptosis. TNF- $\alpha$ and Jo2 induced iNOS messenger RNA and protein levels through the induction of NF-кB. S-nitroso-Nacetylpenicillamine inhibited Bid cleavage, the mitochondrial permeability transition, cytochrome $c$ release, and caspase- 8 and -3 activity, and reduced TNF- $\alpha-$ and Fas-mediated death in hepatocytes expressing ІкB superrepressor. $N^{G}$-methyl-L-arginine acetate partially sensitized hepatocytes to TNF- $\alpha-$ and Fas-mediated cell killing. TNF- $\alpha$ alone or Jo 2 alone induced moderate cell death in hepatocytes from iNOS ${ }^{-}-$mice. Conclusions: NO protects hepatocytes from TNF- $\alpha$ - and Fas-mediated apoptosis. Endogenous iNOS, which is activated by NF-KB via IKK $\beta$, provides partial protection from apoptosis.

$\mathrm{T}$ he tumor necrosis factor $\alpha$ receptor (TNFR) family includes Fas (also known as APO-1 or CD95), the receptor for Fas ligand ${ }^{1}$ (FasL), and 2 TNFRs (TNFR1 and TNFR2). Two death factors, tumor necrosis factor $\alpha$ (TNF- $\alpha$ ) and FasL, bind to their receptors and induce apoptosis, killing the cells within hours. ${ }^{1,2}$ TNF both induces apoptosis and activates the antiapoptotic transcription factor nuclear factor- $-\mathrm{B}(\mathrm{NF}-\kappa \mathrm{B})$. TNFR 1 con- tains a death domain, TNF- $\alpha$ receptor-associated death domain protein (TRADD), which interacts with TNF- $\alpha$ receptor-associated factor 2 (TRAF2). The interaction of TRADD with TRAF2 and protein kinase receptor interacting protein activates NF- $\mathrm{KB}$-inducing kinase (NIK), a mitogen-activated protein kinase kinase kinase (MAPKKK). ${ }^{3-5}$ NIK or another unknown MAPKKK activates the I $\mathrm{I} B$ kinase (IKK) complex, which contains IKK $\alpha$ and IKK $\beta$ and phosphorylates IкB, which leads to its degradation and subsequent activation of NF- $\kappa \mathrm{B} .{ }^{6-9}$ Studies with cells from knockout mice suggest that $\mathrm{IKK} \beta$, but not IKK $\alpha$, is required for TNF- $\alpha$-induced NF- $\kappa \mathrm{B}$ activation. ${ }^{10-12}$ The activation of the NF- $\kappa \mathrm{B}$ by TNF protects from cell killing. ${ }^{13,14}$ TNFR-associated factor 1, TRAF2, and the inhibitor-of-apoptosis (IAP) proteins c-IAP1 and c-IAP2 were identified as gene targets of NF- $\mathrm{KB}$ transcriptional activity. ${ }^{15}$ Other antiapoptotic genes include IEX-1, A1, and A20. ${ }^{16-19}$

The Fas/FasL system is of major importance in homeostasis of the organism, in regulation of the immune system, and in many diseases in which apoptosis plays a role. ${ }^{20}$ Numerous cells in the liver have been shown to express Fas/FasL, and the Fas/FasL system plays a major role in the pathogenesis of many liver diseases, such as viral hepatitis,

\footnotetext{
Abbreviations used in this paper: FasL, Fas ligand; HDM, hormonally defined medium; IAP, inhibitor-of-apoptosis; IFN- $\gamma$, interferon $\gamma$; IKK,

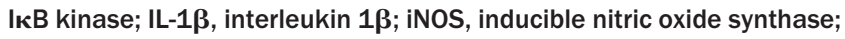
L-NMMA, $\quad N^{G}$-methyl-L-arginine acetate; MAPKKK, mitogen-activated protein kinase kinase kinase; MPT, mitochondrial permeability transition; NF-кB, nuclear factor-кB; NIK, NF-кB-inducing kinase; NO, nitric oxide; PCR, polymerase chain reaction; SDS, sodium dodecyl sulfate; SNAP, S-nitroso-N-acetylpenicillamine; TMRM, tetramethylrhodamine methyl ester; TNF- $\alpha$, tumor necrosis factor $\alpha$; TNFR, tumor necrosis factor $\alpha$ receptor; TRADD, tumor necrosis factor $\alpha$ receptor-associated death domain protein; TRAF2, tumor necrosis factor $\alpha$ receptor-associated factor 2; TUNEL, terminal deoxynucleotidyl transferase-mediated deoxyuridine triphosphate nick end labeling.

(C) 2001 by the American Gastroenterological Association 0016-5085/01/ $\$ 35.00$ doi:10.1053/gast.2001.23239
} 
alcoholic hepatitis, acute liver failure, graft versus host disease, and hepatocellular carcinoma. ${ }^{21-23}$ Activating Fas by FasL or anti-Fas agonistic antibodies such as Jo2 produces fulminant hepatitis in mice. However, many Fasexpressing cells including hepatocytes are resistant to Fasinduced apoptosis in culture, suggesting that cellular factors exist that inhibit Fas signaling. We have previously shown that the IкB superrepressor or the proteasome inhibitor MG-132 sensitized hepatocytes to Fas-mediated apoptosis, which indicates that NF- $\mathrm{KB}$ also has a protective role in Fas-mediated apoptosis. ${ }^{24}$ However, how Fas activates $\mathrm{NF}-\kappa \mathrm{B}$ or which NF- $\mathrm{KB}$ responsive gene has a protective role in Fas-mediated apoptosis is unclear.

Nitric oxide (NO) acts as either a physiologic regulator or a cytotoxic agent. ${ }^{25,26} \mathrm{NO}$ may cause hepatocyte injury, primarily through the induction of hepatocyte apoptosis. ${ }^{27}$ Alternatively, NO can induce resistance to TNF- $\alpha$-induced hepatotoxicity. NO may prevent apoptosis in hepatocytes by inhibiting caspase-3-like activation via a guanosine $3^{\prime}, 5^{\prime}$-cyclic monophosphate (cGMP) -dependent mechanism and by direct inhibition of caspase-3-like activity through protein S-nitrosylation. ${ }^{28}$ NO may also inhibit TNF- $\alpha$-induced hepatotoxicity through the stimulation of heat shock protein 70 expression. ${ }^{29}$

The cytokines TNF- $\alpha$, interleukin $1 \beta$ (IL- $1 \beta$ ), and interferon $\gamma$ (IFN- $\gamma$ ) synergistically activate inducible nitric oxide synthase (iNOS) expression in the liver. ${ }^{30}$ However, the association between Fas signaling pathway and iNOS is unknown. In general, iNOS gene expression requires the transcription factor NF-KB. ${ }^{30}$ This study examines the roles of NF- $\kappa \mathrm{B}$ activation, iNOS expression, and NO synthesis in TNF- $\alpha-$ and Fas-mediated apoptosis in primary mouse hepatocytes.

\section{Materials and Methods}

\section{Primary Hepatocyte Cultures}

About 8-week-old C57B16 male mice were anesthetized with ketamine/acepromazine malate administered by intraperitoneal injection. Hepatocytes were then isolated by a retrograde, nonrecirculating in situ collagenase perfusion of livers cannulating through the inferior vena cava by a procedure modified from Moldeus et al. ${ }^{31}$ Livers were first perfused in situ with an oxygenated $0.5 \mathrm{mmol} / \mathrm{L}$ ethylene glycol-bis $(\beta$ aminoethyl ether)- $N, N, N^{\prime}, N^{\prime}$-tetraacetic acid containing calcium-free salt solution $\left(10 \mathrm{~mL} / \mathrm{min}, 37^{\circ} \mathrm{C}\right.$ for 5 minutes $)$, followed by perfusion with solution containing $0.04 \%$ collagenase type I (Worthington biochemical corporation, Lakewood, NJ) for 10 minutes. The liver was then gently minced on a Petri dish and filtered with polyamide mesh (I $003 \mathrm{Y}$ NITEX 3-60/45; TETKO Inc., Depew, NY). Hepatocytes were washed 2 times and centrifuged at $50 \mathrm{~g}$ for 2 minutes. Cell viability was consistently $>90 \%$ as determined by trypan blue exclusion. Hepatocyte cultures contained less than $1 \%$ Kupffer cells and hepatic stellate cells as determined by fluorescein isothiocyanate-labeled latex beads ( $1 \mu \mathrm{m}$; Polysciences, Warrington, PA) and autofluorescence, respectively. $4 \times 10^{5}$ cells were plated on 6-well plates coated with mouse collagen type I in Waymouth's medium containing $10 \%$ fetal bovine serum, $0.1 \mu \mathrm{mol} / \mathrm{L}$ insulin, and $0.1 \mu \mathrm{mol} / \mathrm{L}$ dexamethazone. $1.5 \times$ $10^{6}$ or $4.0 \times 10^{6}$ cells were plated on a $60-\mathrm{mm}$ or $100-\mathrm{mm}$ dish, respectively. After 1.5 to 2 hours, the culture was washed with phosphate-buffered saline and changed to hormonally defined medium (HDM) containing $0.1 \mu \mathrm{mol} / \mathrm{L}$ insulin, 2 $\mathrm{mmol} / \mathrm{L}$ L-glutamine, $5 \mu \mathrm{g} / \mathrm{mL}$ transferrin, $3 \mu \mathrm{mol} / \mathrm{L}$ selenium, and $10 \mathrm{nmol} / \mathrm{L}$ free fatty acids in RPMI basal medium. Cells were infected with recombinant adenoviruses in HDM containing 30 plaque forming units/cell for 2 hours at $37^{\circ} \mathrm{C}$ and then changed to HDM containing recombinant murine TNF- $\alpha$ (R\&D Systems, Minneapolis, MN), Jo-2 (Pharmingen, San Diego, CA), or other treatments. In some experiments, cells were pretreated with $\mathrm{NO}$ donor, $S$-nitroso- $N$-acetylpenicillamine (SNAP; Molecular Probes, Eugene, OR), or NOS inhibitor, $N^{G}$-methyl-L-arginine acetate (L-NMMA; Molecular Probes) for 2 hours before the exposure of TNF- $\alpha$ or Jo2. Furthermore, iNOS-null hepatocytes were isolated from iNOS knockout mice (a kind gift from Dr. O. Smithies and Dr. N. Maeda). ${ }^{32}$ All animals received humane care in compliance with the guidelines of the University of North Carolina.

\section{Adenoviruses}

The adenovirus 5 variants $\mathrm{Ad} 5 \mathrm{I} \kappa \mathrm{B}$ and $\mathrm{Ad} 5 \mathrm{LacZ}$ expressing HA-IкB $\alpha(\mathrm{S} 32 \mathrm{~A}, \mathrm{~S} 36 \mathrm{~A})$ and $\beta$-galactosidase, respectively, have been described elsewhere. ${ }^{33,34}$ The adenoviruses, Ad5IKK $\alpha \mathrm{dn}$ or Ad5IKK $\beta \mathrm{dn}$ were expressing a catalytic mutant with lysine changed to methionine. Lysates were prepared from $4 \times 10^{5}$ hepatocytes at 24 hours after adenoviral infection. The HA-tagged IKK $\alpha \mathrm{dn}$ or the FLAG-tagged IKK $\beta \mathrm{dn}$ were detected using mouse anti-HA antibody (Boehringer Mannheim, Mannheim, Germany) or mouse anti-FLAG antibody (Eastman Kodak Company, New Haven, CT), respectively.

\section{Nuclear Extract Preparation and Electrophoretic Mobility Shift Assay}

Four million cells were cultured overnight after adenoviral infection. Cells were harvested 30 minutes after TNF- $\alpha$ or Jo2 treatment. Nuclear protein extracts were prepared from primary mouse hepatocytes as previously described. ${ }^{33,34}$ Protein-DNA binding reactions were performed for 20 minutes on ice, using $5 \mu \mathrm{g}$ of nuclear extract and ${ }^{32} \mathrm{P}$-labeled DNA probes for the NF- $\mathrm{KB}$ consensus binding site. ${ }^{35}$ Complexes were separated by electrophoresis on nondenaturing 5\% acrylamide gels and assayed by autoradiography and PhosphorImager analysis (Molecular Dynamics, Sunnyvale, CA). For supershift assays, $8 \mu \mathrm{g}$ of antibody against $\mathrm{p} 65$ or p 50 subunit of the NF-кB complex (Santa Cruz Biotechnology, Santa Cruz, 
CA) was added to the reaction mixture, and the incubation time was extended for an additional 30 minutes.

\section{Measurement of Apoptosis}

For quantitation of cell viability (presented as mean \pm SEM), cells were infected and treated as described above. After 17 to 20 hours of TNF- $\alpha$ or Jo- 2 treatment, cell viability was determined by exclusion of trypan blue. Viable cells were counted in 3 different $200 \times$ power fields, and the percentage of treated viable cells to untreated viable cells was determined as a percentage of control viability. For propidium iodide nuclear staining, cells were fixed in 3:1 methanol/acetic acid, stained with 10 $\mu \mathrm{g} / \mathrm{mL}$ propidium iodide, and viewed with an Olympus fluorescence microscope (Olympus America, Melville, NY) using a rhodamine filter set. Hepatocyte cell death was confirmed as apoptosis by terminal deoxynucleotidyl transferase-mediated deoxyuridine triphosphate nick end labeling (TUNEL; Boehringer Mannheim). TUNEL staining was performed according to the manufacturer's instructions. Positive (apoptotic) cells were counted in 3 different $200 \times$ power fields. 7-amino-4-triflouromethyl coumarin (AFC) release assays for caspase- 3 and -8 activities were performed using the FluorAce kit (Bio-Rad Laboratories, Hercules, CA) according to the manufacturer's instructions. Briefly, whole cell lysates were combined with $25 \mu \mathrm{mol} / \mathrm{L} z-$ DEVD-AFC or IETD-AFC (Enzyme and Systems Products, Livermore, CA) and were incubated 2 hours at $37^{\circ} \mathrm{C}$. Change in fluorescence (excitation at $370 \mathrm{~nm}$ and emission at $490 \mathrm{~nm}$ ) was monitored at 1-hour intervals, converted to picomoles of AFC released by using a standard curve, and normalized for protein concentration.

\section{Reverse-transcription Polymerase Chain Reaction for iNOS}

Total RNA was extracted with RNeasy mini kit (Qiagen Inc., Valencia, CA) according to the manufacturer's instructions. First-strand complementary DNA was synthesized using $1 \mu \mathrm{g}$ of total RNA, $10 \mathrm{mmol} / \mathrm{L}$ deoxynucleoside triphosphates (Pharmacia, Piscataway, NJ), and $200 \mathrm{U}$ of Moloney Murine leukemia virus reverse transcriptase (Gibco, Grand Island, NY) in a final volume of $25 \mu \mathrm{L}$. The reaction was performed for 60 minutes at $42^{\circ} \mathrm{C}$. The synthesized complementary DNA was amplified using specific sets of primers for iNOS and $\beta$-actin. The iNOS sense primer sequence was 5'-TAGAAACAACAGGAACCTACCA-3', and the antisense primer was 5'-ACAGGGGTGATGCTCCATGACA-3'. The primers for $\beta$-actin were described before. ${ }^{35}$ Polymerase chain reactions (PCRs) were cycled as follows after initial denaturation for 4 minutes at $99.9^{\circ} \mathrm{C}$ : 40 cycles: $94^{\circ} \mathrm{C}$ for 30 seconds, $58^{\circ} \mathrm{C}$ for 30 seconds, and $72^{\circ} \mathrm{C}$ for 30 seconds; final extension was carried out at $72^{\circ} \mathrm{C}$ for 5 minutes. PCR products were electrophoresed in a $2 \%$ agarose gel, stained with ethidium bromide, and photographed.

\section{Western Blot Analysis}

Cell lysates were prepared from $4 \times 10^{6}$ hepatocytes with or without Ad5IкB infection. Lysates containing $25 \mu \mathrm{g}$,
$50 \mu \mathrm{g}$, or $50 \mu \mathrm{g}$ of protein were separated by electrophoresis on $7.5 \%, 10 \%$, or $10 \%$ acrylamide sodium dodecyl sulfate (SDS) gels for iNOS, caspase-8, or Bid, respectively. The proteins were transferred into nitocellulose membranes (Schleicher \& Schuell, Keene, NH). Equal loading was confirmed by Ponceau S staining. iNOS was detected using rabbit polyclonal anti-iNOS antibody (Santa Cruz Biotechnology) and secondary antirabbit horseradish peroxidase-conjugated antibody (Santa Cruz Biotechnology). Antirat albumin antibody (Pharmaceuticals, Inc., Aurora, $\mathrm{OH}$ ) was used for internal control. Caspase- 8 cleavage products, p18, were detected using rabbit polyclonal anti-caspase- 8 antibody (Stressgen, Victoria, BC, Canada) and secondary antirabbit horseradish peroxidase-conjugated antibody (Santa Cruz Biotechnology). Bid was detected using primary polyclonal rabbit Bid antibody (a kind gift from Dr. X. M. Yin) and secondary antirabbit horseradish peroxidase-conjugated antibody. Proteins were detected with enhanced chemLuminesence detection reagents (Amersham Corp., Arlington Heights, IL).

The preparation of cytosolic S-100 fractions and Western blot analysis for cytochrome $c$ were performed as described previously. ${ }^{33}$ Briefly, S-100 fractions were prepared from $8 \times$ $10^{6}$ hepatocytes by differential centrifugation in buffer containing $250 \mathrm{mmol} / \mathrm{L}$ sucrose. Lysates containing $25 \mu \mathrm{g}$ of protein were separated by electrophoresis on $15 \%$ acrylamide SDS gels and transferred into nitocellulose membranes (Schleicher \& Schuell). Equal loading was confirmed by Ponceau S staining. Cytochrome $c$ was detected using primary monoclonal anti-cytochrome $c$ antibody (Pharmingen) and secondary anti-mouse horseradish peroxidase-conjugated antibody (Santa Cruz Biotechnology).

\section{Nitrite + Nitrate Assay}

$4 \times 10^{5}$ hepatocytes were plated onto a 6-well plate. Culture supernatants were collected 24 hours after treatment and assayed for nitrite and nitrate $\left(\mathrm{NO}_{2}{ }^{-}+\mathrm{NO}_{3}{ }^{-}\right)$using Griess Reagent kit (Molecular Probes) according to the manufacturer's instructions.

\section{Confocal Microscopy}

Cell loading and confocal microscopy were performed as described previously. ${ }^{33}$ Briefly, $1.5 \times 10^{6}$ hepatocytes plated on collagen-coated 40-mm-diameter glass coverslips were infected with $\mathrm{Ad} 5 \mathrm{I}$ І B with or without the pretreatment with SNAP in HDM supplemented with $50 \mathrm{mmol} / \mathrm{L}$ HEPES $(\mathrm{pH} 7.0)$ to stabilize the $\mathrm{pH}$ during the confocal measurements. The cells were loaded with $250 \mathrm{nmol} / \mathrm{L}$ tetramethylrhodamine methyl ester (TMRM; Molecular Probes) and 1 $\mu \mathrm{mol} / \mathrm{L}$ calcein-acetoxymethyl ester (Molecular Probes) in Krebb Ringer Hepes buffer for 15 minutes at $37^{\circ} \mathrm{C}$. The coverslips were mounted on a Nikon microscope (Nikon, Melville, NY) in HDM-HEPES containing $100 \mathrm{nmol} / \mathrm{L}$ TMRM, and the temperature was maintained at $37^{\circ} \mathrm{C}$. The first image (time-point 0) was then recorded. Subsequently, TNF- $\alpha$ or Jo- 2 was added to the medium, and images were collected at given time-points. Calcein and TMRM fluores- 
cence were excited with an argon laser through a double dichroic reflector at $488 \mathrm{~nm}$ and $568 \mathrm{~nm}$, respectively. TMRM was imaged through a 590-nm-long path emission filter using a Bio-Rad MRC-600 confocal system (Bio-Rad Laboratories). Calcein fluorescence was collected through a 515-560-nm band path emission filter. A numerical aperture $1.4,60 \times$ objective lens was used, and pinholes were set to 4 in both channels. Laser attenuation and power were set at $0.3 \%$ and low, respectively.

\section{Results}

\section{IKB Superrepressor and dnIKK $\beta$ Inhibit the Induction of NFKB Binding Activity by TNF- $\alpha$ or Anti-Fas Antibody}

To determine the roles of NF- $\mathrm{KB}$ and IKKs in TNF- $\alpha$ - and Fas-mediated apoptosis in primary mouse hepatocytes, adenoviruses expressing an HA-tagged kinaseinactive mutant of IKK $\alpha(\operatorname{dnIKK} \alpha)$ and a FLAG-tagged kinase-inactive mutant of IKK $\beta$ were generated. NF- $\mathrm{BB}$ binding activity was assessed by mobility shift assays using an NF-KB binding site as a probe. Nuclear extracts were prepared from primary mouse hepatocytes 30 minutes after treatment of TNF- $\alpha$ or anti-Fas agonistic antibody, Jo2, with or without adenoviral infection. TNF- $\alpha$ treatment for 30 minutes induced an increase in NF- $\mathrm{KB}$ DNA binding activity (Figure $1 A$ ), as described before. ${ }^{24}$ Expression of $\operatorname{dnIKK} \beta$ or the IкB superrepressor completely inhibited TNF- $\alpha$-induced NF- $\kappa B$ binding activity. The $\operatorname{dnIKK} \alpha$ suppressed TNF- $\alpha$-induced NF- $\kappa B$ binding activity to a lesser extent than dnIKK $\beta$. Furthermore, Jo2 treatment also induced NF-кB binding activity (Figure 1B). Jo2induced NF- $\kappa \mathrm{B}$ binding activity was completely inhibited in IкB superrepressor- and dnIKK $\beta$-expressing hepatocytes. The NF- $\mathrm{BB}$ complex activated by TNF- $\alpha$ or Jo2 treatment was composed of p50-p65 dimers, as determined by supershifts (Figure $1 A$ and $B$ ). Control adenovirus expressing $\beta$-galactosidase had no effect on TNF- $\alpha$ - or Jo2induced NF- $\kappa \mathrm{B}$ binding activity (data not shown). These results show that TNF- $\alpha$ and Jo2 activate NF- $\kappa B$ through IKKs, especially IKK $\beta$, in mouse hepatocytes.

\section{The dnIKK $\beta$ Expression Sensitizes Mouse Hepatocytes to TNF- $\alpha$ - or Fas-mediated Apoptosis}

To investigate the roles of IKKs in TNF- $\alpha$ - and Fas-mediated hepatocyte apoptosis, we infected mouse hepatocytes with dnIKK $\alpha$ adenovirus or $\operatorname{dnIKK} \beta$ adenovirus and treated cells with TNF- $\alpha$ or anti-Fas antibody. The expression of the IKKs was confirmed by Western blotting using HA or FLAG tag (Figure 2C, upper panel). TNF- $\alpha$ or Jo 2 treatment killed the hepatocytes expressing dnIKK $\beta$, but not $\operatorname{dnIKK} \alpha$ (Figure $2 A$

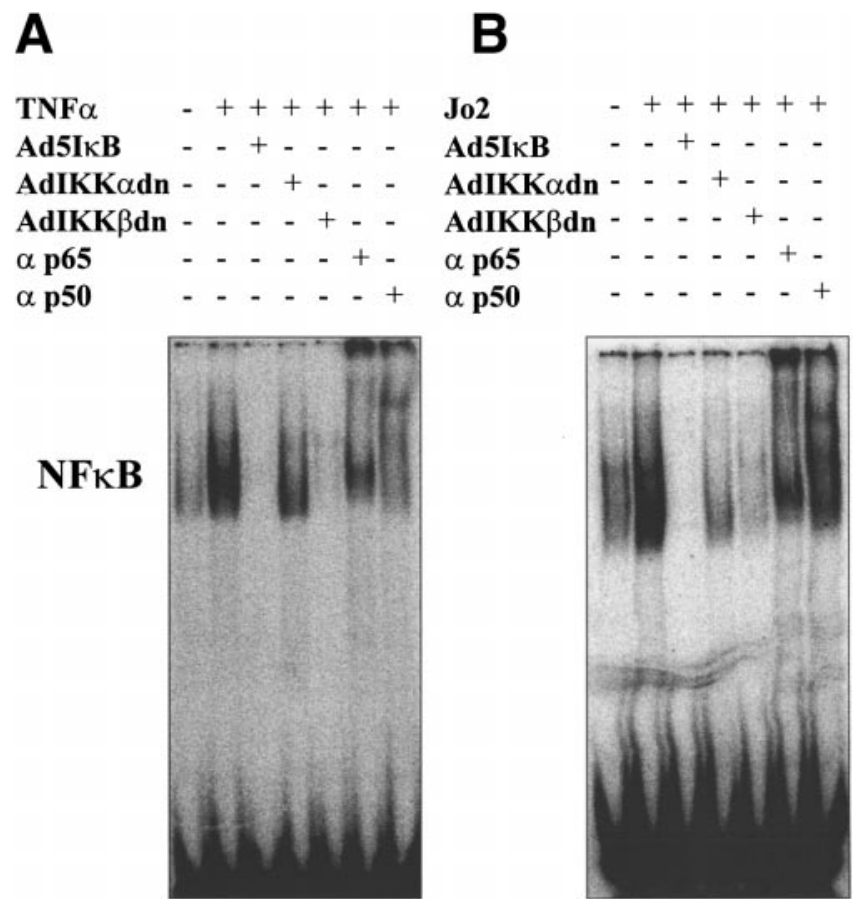

Figure 1. The IкB superrepressor or dominant-negative form of IKK $\beta$ blocks TNF- $\alpha-$ and Fas-mediated NF-kB binding activity. NF-kB DNA binding activity was assessed by an electrophoretic mobility shift assay using an NF- $\mathrm{KB}$ binding site as the probe with nuclear extracts prepared after a 30-minute incubation with $(A)$ TNF- $\alpha$ or $(B)$ Jo2 with or without adenovirus infection with Ad5IKB, Ad5IKK $\alpha d n, A d 5 I K K \beta d n(30$ multiplicity of infection [MOI]) for 2 hours. For supershift assays, $8 \mu g$ of antibody against p65 or p50 subunit of the NF-kB complex was added to the reaction mixture, and the incubation time was extended for an additional 30 minutes.

and $C$ ). The hepatocytes expressing $\operatorname{dnIKK} \beta$ treated with TNF- $\alpha$ or Jo2 displayed nuclear condensation and fragmentation by propidium iodide staining, characteristic of apoptosis (Figure 2B, right panel), whereas cells expressing $\operatorname{dnIKK} \alpha$ displayed almost normal nuclear morphology after TNF- $\alpha$ or Jo2 treatment (Figure $2 B$, left panel). To confirm death by apoptosis, a TUNEL assay was performed. Although TUNEL-positive cells were minimal after TNF- $\alpha$ or Jo2 treatment in hepatocytes expressing $\operatorname{dnIKK} \alpha(2.0 \pm 1.0,11.7 \pm 1.5$, mean \pm SEM cells $/ \times 200$, respectively), positive hepatocytes were observed after TNF- $\alpha$ or Jo2 treatment in $\operatorname{dnIKK} \beta$ adenovirus-infected hepatocytes $(57.7 \pm 5.2$ and $50.0 \pm 5.3$, respectively). These results show that NF- $\mathrm{KB}$ activation, mediated by IKK $\beta$, but not IKK $\alpha$, protects primary mouse hepatocytes from TNF- $\alpha$ - or Fas-mediated apoptosis.

\section{TNF- $\alpha$ or anti-Fas Antibody Induces iNOS Expression, Which Is Blocked by lкB Superrepressor}

A critical question is which NF- $\kappa \mathrm{B}-$-responsive gene protects hepatocytes from TNF- $\alpha$ - or Fas-mediated apopto- 

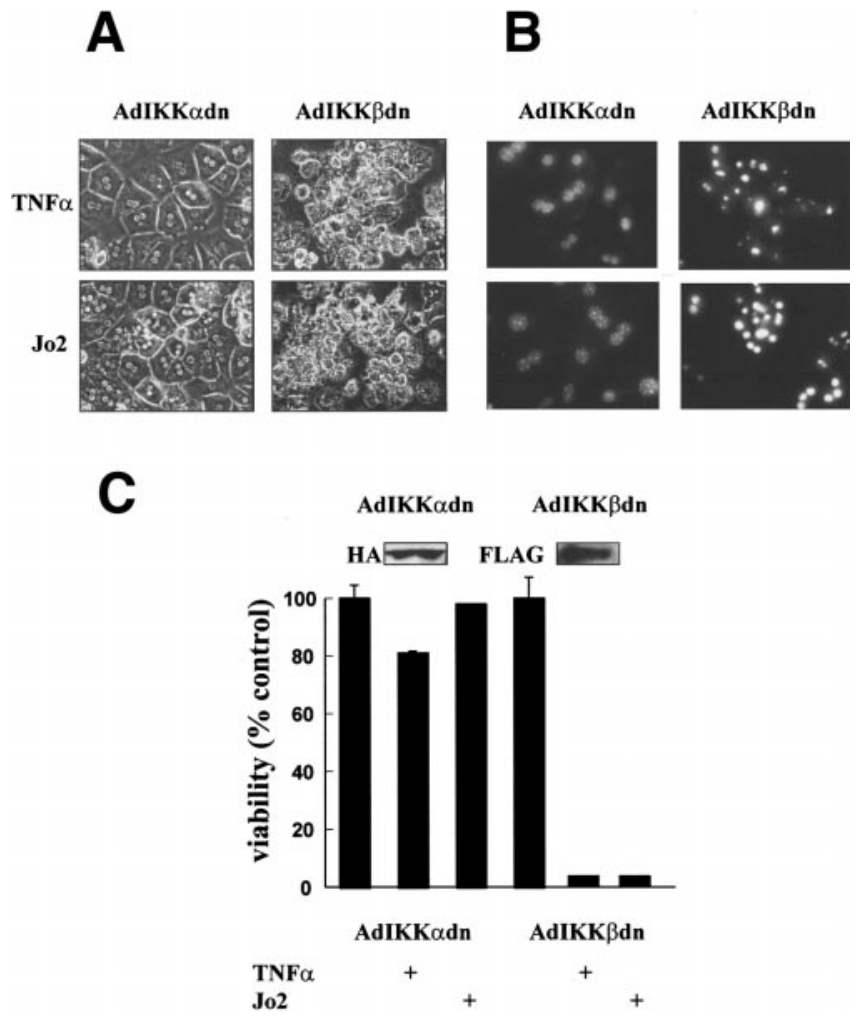

Figure 2. The dominant-negative form of IKK $\beta$, but not IKK $\alpha$, sensitizes mouse hepatocytes to TNF- $\alpha$ - and Fas-mediated apoptosis. (A) Primary mouse hepatocytes were treated with TNF- $\alpha$ (30 ng/mL, upper panel) or Jo2 $(0.5 \mu \mathrm{g} / \mathrm{mL}$, lower panel) after AdIKK $\alpha \mathrm{dn}$ or AdlKK $\beta \mathrm{dn}$ infection (30 MOI). Phase contrast images of mouse hepatocytes were obtained at 21 hours after the treatment (original magnification 200 $\times$ ). (B) Propidium iodide-stained images of TNF- $\alpha$-treated (upper panel) and Jo2-treated cells (lower panel) at 17 hours after the treatment (original magnification $400 \times$ ). (C) The HA-tagged IKK $\alpha$ dn or the FLAG-tagged IKK $\beta d n$ was detected by Western blotting in whole extracts after adenovirus infection using anti-HA antibody or anti-FLAG antibody, respectively (upper panel). Cell viability was assessed after 20 hours by a trypan blue exclusion test. Data are shown as average percent viability \pm SEM of 2 to 4 different experiments (lower panel).

sis. Among antiapoptotic NF-кB responsive genes, we focused on iNOS, which synthesizes NO. iNOS is an NF$\kappa \mathrm{B}-$ responsive gene induced by TNF. ${ }^{30} \mathrm{NO}$, the product of iNOS, is a protective factor against TNF toxicity in several cell types. ${ }^{28,36}$ To determine if TNF- $\alpha$ and Jo2 induce iNOS, we performed reverse-transcription PCR and Western blot analysis for iNOS. TNF- $\alpha$ induced iNOS messenger RNA (mRNA) by 1 hour after treatment with higher iNOS mRNA levels at 2 and 4 hours (Figure $3 A$ ). Jo2 induced iNOS mRNA after 4 hours of treatment. These results indicate iNOS mRNA expression precedes caspase-3 activation in TNF- $\alpha$ - and Fas-mediated apoptosis. ${ }^{24}$ The iNOS mRNA expression was blocked in hepatocytes expressing the ІкВ superrepressor. Consistent with the mRNA results, iNOS protein was induced by TNF- $\alpha$ or Jo2, which was blocked by Ad5IкB infection (Figure 3B).
As expected, TNF- $\alpha$ or Jo2 does not induce iNOS in iNOS knockout hepatocytes (Figure 3B). Treatment with TNF- $\alpha$ or Jo2 produced NO, as documented by the accumulation of nitrite and nitrate in the media (Figure $4 \mathrm{~A}$ ). These results indicate that TNF- $\alpha$ or anti-Fas agonistic antibody induces iNOS expression, which is blocked by IкB superrepressor, and that iNOS is an NF- $\mathrm{kB}$-responsive gene in hepatocytes.

\section{NO Protects Mouse Hepatocytes From TNF- $\alpha$ - or Fas-mediated Apoptosis}

To explore the effect of iNOS and NO in TNF- $\alpha$ - or Fas-mediated apoptosis, we used the NO donor SNAP in the mouse hepatocytes. SNAP produced NO, as documented by the accumulation of nitrite and nitrate in the media (Figure $4 A$ ). Because $\mathrm{NO}$ enhances activation of NF- $\kappa \mathrm{B}$ in some other cell types, ${ }^{37}$ we determined whether NO activates NF- $\kappa \mathrm{B}$. However, SNAP reduced NF- $\mathrm{KB}$ binding activity by TNF- $\alpha$ or Jo2 in hepatocytes, whereas the IкB superrepressor completely blocks NF- $\mathrm{BB}$ binding activity by TNF- $\alpha$ or Jo2 (Figure $4 B$ ). Hepatocytes expressing IкB superrepressor were treated with TNF- $\alpha$ or Jo2 with or without pretreatment with SNAP. Without

\section{A}

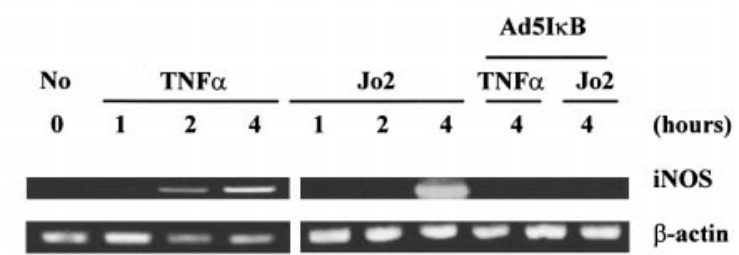

B

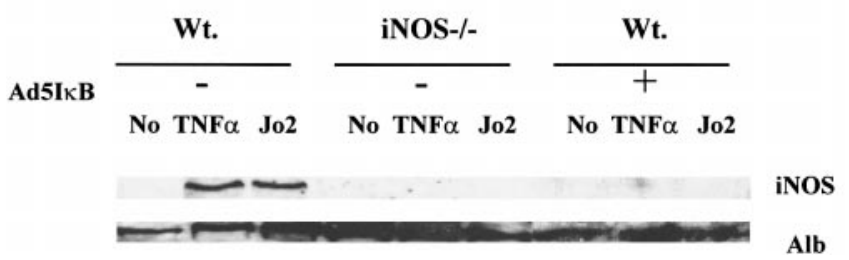

Figure 3. TNF- $\alpha$ or anti-Fas antibody induces iNOS expression, which is blocked by the IKB superrepressor. (A) Total RNA was extracted at the indicated times after treatment with TNF- $\alpha$ (30 $\mathrm{ng} / \mathrm{mL})$ or Jo2 $(0.5 \mu \mathrm{g} / \mathrm{mL})$. Some cultures were pretreated by Ad5/кB infection. iNOS mRNAs were measured using reverse-transcription PCR analysis as described in Materials and Methods. (B) Lysates were prepared from $4 \times 10^{6}$ hepatocytes at 24 hours after TNF- $\alpha$ or Jo2 treatment. Lysates containing $25 \mu \mathrm{g}$ protein were separated by electrophoresis on $7.5 \%$ acrylamide SDS gel. iNOS (upper panel) was detected by the Western blotting. Albumin was also detected for the internal control. 


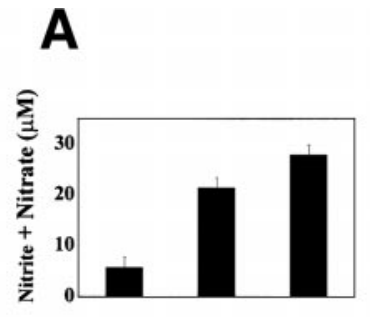

\section{B}

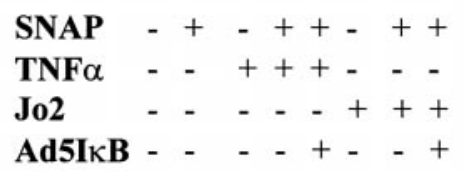

SNAP $(\mu M) \quad 0 \quad 250 \quad 500$

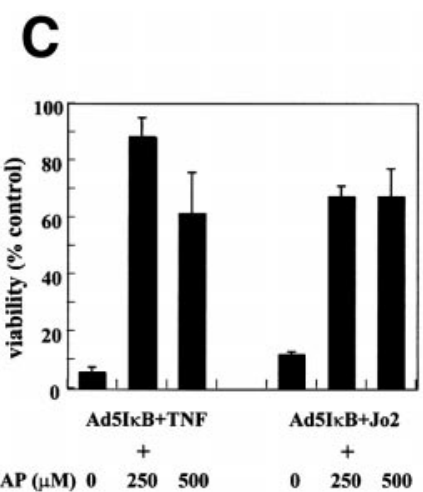

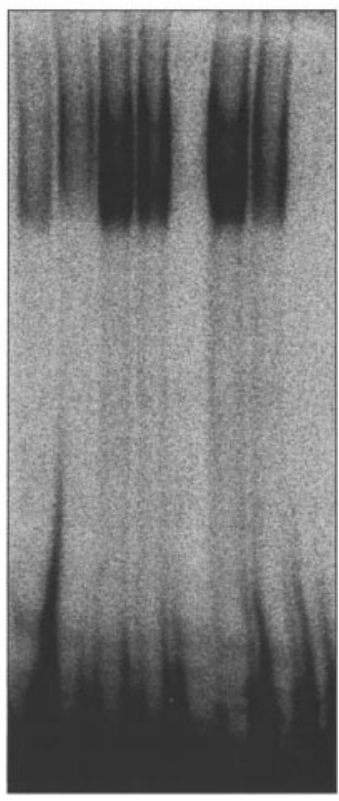

Figure 4. NO donor, SNAP, protects mouse hepatocytes from TNF- $\alpha-$ and Fas-mediated apoptosis. (A) Cultured mouse hepatocytes were treated with SNAP, TNF- $\alpha$, or Jo2. Culture media were collected 24 hours after treatment and $\mathrm{NO}_{2}{ }^{-}+\mathrm{NO}_{3}{ }^{-}$release were measured by the Griess reaction. Values are expressed as the mean \pm SEM of 2 different experiments. (B) NF-kB DNA binding activity was assessed by an electrophoretic mobility shift assay using an NF-kB binding site as the probe with nuclear extracts prepared after a 30-minute incubation with TNF- $\alpha$ or Jo2 with or without the pretreatment of SNAP for 2 hours. $(C)$ Cell viability was assessed at 17 hours after TNF- $\alpha$ or Jo2 treatment with or without the pretreatment of SNAP in hepatocytes expressing $\mathrm{I}_{\mathrm{K}} \mathrm{B}$ superrepressor by a trypan blue exclusion test. Data are shown as average percent viability \pm SEM of 2 to 4 different experiments.

SNAP, the expression of IкB superrepressor sensitizes hepatocytes to TNF- $\alpha$ - and Fas-mediated cell killing, as described before ${ }^{24,33}$ (Figure $4 C$ ). In contrast, SNAP significantly blocked TNF- $\alpha$ - and Fas-mediated cell killing. However, more than $500 \mu \mathrm{mol} / \mathrm{L}$ of SNAP was toxic to the hepatocytes. NO may also inhibit TNF- $\alpha$-induced hepatotoxicity through the stimulation of heat shock protein 70 expression. ${ }^{29}$ However, $250 \mu \mathrm{mol} / \mathrm{L}$ of SNAP was not sufficient for induction of heat shock protein 70, shown by Western blot analysis (Kim et al. ${ }^{29}$ and data not shown). These results showed that moderate exogenous NO levels protect hepatocytes from TNF- $\alpha$ - and Fas-mediated cell killing and that this protective effect is not a result of NF- $\mathrm{kB}$ activation by $\mathrm{NO}$ or heat shock protein 70 induction.

\section{NO Blocks TNF- $\alpha$ - and Fas-mediated Activation of Caspase-8, Bid, and Caspase-3}

To determine the mechanism by which NO blocks TNF- $\alpha$ - and Fas-mediated apoptosis, we investigated the expression of Bid and activation of caspase- 8 and caspase- 3 with or without the pretreatment with SNAP. The cleavage product of caspase- $8, \mathrm{p} 18$, was detected in cell lysates from hepatocytes 6 hours after TNF- $\alpha$ treatment and 1.5 hours after Jo2 treatment. However, SNAP inhibited activation of caspase-8 (Fig-

A

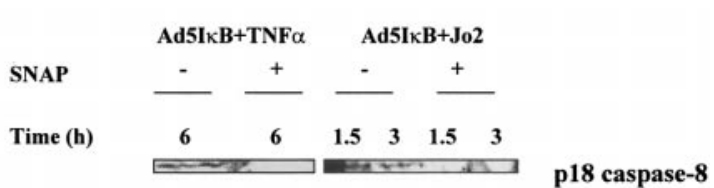

B

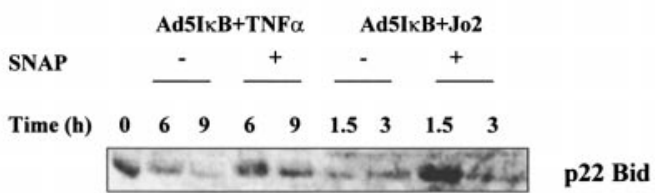

C

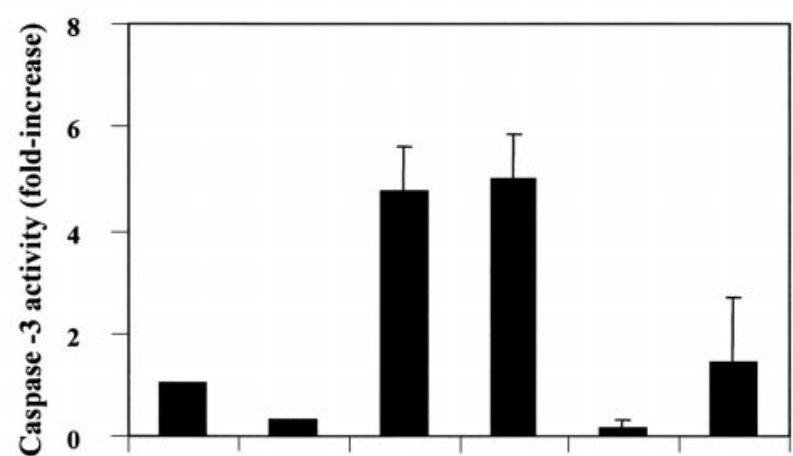

$\begin{array}{lllllll}\text { SNAP } & - & + & - & - & + & + \\ \text { Ad5I } \kappa \text { B } & - & - & + & + & + & + \\ \text { TNF } \alpha & - & - & + & - & + & - \\ \text { Jo2 - } & - & - & - & + & - & +\end{array}$

Figure 5. NO blocks TNF- $\alpha$ - and Fas-induced activation of caspase-8, $\mathrm{Bid}$, and caspase-3. Hepatocytes were either treated with TNF- $\alpha$ or Jo2 after Ad5ІкB infection. Some cultures were pretreated by SNAP. Cell lysates were prepared $\left(4 \times 10^{6}\right.$ cells $)$ at the times indicated. Caspase-8 cleavage product, p18 $(A)$, and p22 Bid $(B)$ were detected by Western blotting as described under Materials and Methods. (C) Ad5IкB-infected hepatocytes were treated with TNF- $\alpha(30 \mathrm{ng} / \mathrm{mL})$ or Jo2 $(0.5 \mu \mathrm{g} / \mathrm{mL})$, and then lysed and assayed for caspase-3 activity at 1-hour intervals. Data are shown as average fold-increases of basal levels without treatment \pm SEM of 2 different experiments performed in duplicate. 
ure $5 A$ ). Furthermore, catalytic assays using IETD-AFC substrate showed SNAP reduced caspase- 8 activivation by TNF- $\alpha$ and Jo 2 in hepatocytes expressing IкB superrepressor (data not shown). Cleavage of Bid mediates mitochondrial dysfunction and cytochrome $c$ in some apoptotic pathways; ${ }^{38,39}$ and Bid is essential for the apoptosis of selected cells, because Bid-deficient mice are resistant to Fas-induced hepatocellular apoptosis. ${ }^{40} \mathrm{Bid}$ was cleaved after TNF- $\alpha$ or Jo2 in hepatocytes expressing the IкB superrepressor (Figure 5B). However, SNAP blocked the cleavage of Bid by TNF- $\alpha$ or Jo2 in hepatocytes expressing IкB superrepressor. The activity of the effector caspase, caspase- 3 , was reduced by the pretreatment with SNAP in TNF- $\alpha$ - and Jo2-treated cells (Figure $5 C$ ).

\section{NO Blocks the Mitochondrial Permeability Transition and Cytochrome $c$ Release Induced by TNF- $\alpha$ or anti-Fas Antibody in Hepatocytes Expressing the IKB Superrepressor}

The mitochondrial permeability transition (MPT) is an essential component in the signaling pathways in TNF- $\alpha$-mediated cytotoxicity in the L929 line of mouse fibroblast ${ }^{41}$ and in TNF- $\alpha$-induced apoptosis in rat and mouse hepatocytes. ${ }^{24,33}$ To determine the effect of $\mathrm{NO}$ on the MPT, we monitored the MPT and mitochondrial depolarization using calcein and TMRM, respectively. TNF- $\alpha$ induced the MPT and mitochondrial depolarization from 8 to 10 hours after treatment in Ad5ІкBinfected hepatocytes (data not shown), as described before in rat and mouse hepatocytes. ${ }^{24,33}$ However, after pretreatment with SNAP, even 10 hours after treatment with TNF- $\alpha$, each TMRM-labeled mitochondrion corresponded to a dark void in the calcein image, showing that the mitochondria were polarized and impermeable to low-molecular-weight solutes (Figure 6A). This result indicates that SNAP blocks the MPT and mitochondrial depolarization. At 3.5 hours after treatment of Jo2, some mitochondria filled with calcein fluorescence (Figure 7 , lower right panel), showing permeabilization of the inner mitochondrial membrane, corresponding to onset of the MPT. Simultaneously, these mitochondria lost TMRM fluorescence, indicating depolarization (Figure 7, upper right panel). In contrast, the dark void in the calcein image was intact at 3.5 hours after Jo2 treatment in Ad5IKB-infected hepatocytes pretreated with SNAP, showing that pretreatment with SNAP clearly maintained mitochondrial function (Figure $8 A$ ).

Western blot analysis for cytochrome $c$ release using in the cytoplasm showed the pretreatment of $250 \mu \mathrm{mol} / \mathrm{L}$ of

\section{Ad5I $\kappa$ B + TNF $\alpha+$ SNAP}

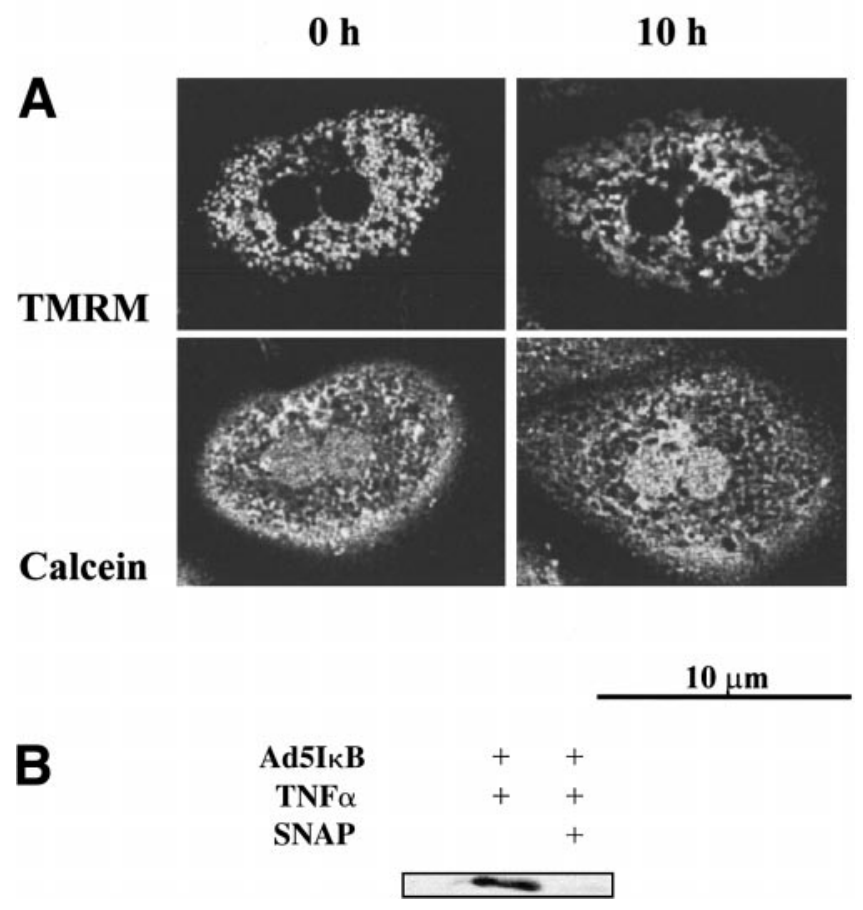

Figure 6. NO donor blocks the MPT and cytochrome $c$ release induced by TNF- $\alpha$ in hepatocytes expressing ІкB superrepressor. $(A)$ Primary mouse hepatocytes were incubated with TNF- $\alpha(30 \mathrm{ng} / \mathrm{mL})$ after Ad5lkB infection (30 MOI), pretreated with SNAP (500 $\mu \mathrm{mol} / \mathrm{L})$, and then loaded with calcein (lower panel) to monitor the MPT and TMRM (upper panel) to monitor mitochondrial depolarization. Calcein and TMRM fluorescence were monitored simultaneously over time by confocal microscopy. The images were obtained before (left panel) and 10 hours after Jo2 treatment (right panel). (B) The preparation of cytosolic S100-fractions and Western blot analysis for cytochrome $c$ were performed as described previously. ${ }^{33}$ SNAP blocked cytochrome $c$ release from mitochondria by TNF- $\alpha$.

SNAP inhibited cytochrome $c$ release by TNF- $\alpha$ (Figure $6 B$ ) or Jo2 (Figure $8 B$ ). Thus, NO inhibits the MPT and cytochrome $c$ release.

\section{NOS Inhibitor Sensitizes Mouse Hepatocytes to TNF- $\alpha$ - or Fas-mediated Apoptosis}

Hepatocytes were pretreated with an iNOS inhibitor at a variety of concentrations before TNF- $\alpha$ or Jo2 treatment. The administration of the iNOS inhibitor, L-NMMA, sensitized hepatocytes to TNF- $\alpha$ - and Fasmediated cell killing without the ІкB superrepressor (Figure 9). L-NMMA increased cell killing by 30\%$70 \%$. These results indicate that iNOS is one of the genes mediating resistance to TNF- $\alpha$ - and Fas-mediated cell killing. 
Ad5I $\kappa$ B+Jo2 $\mathbf{0 ~ h}$

\section{A \\ TMRM}

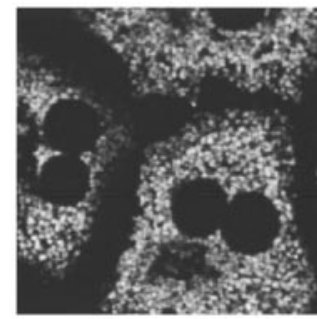

B

Calcein

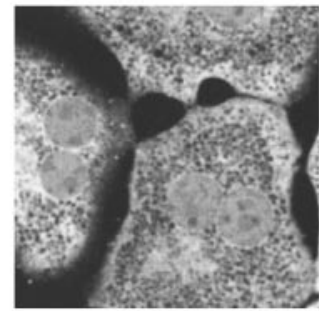

$3.5 \mathrm{~h}$
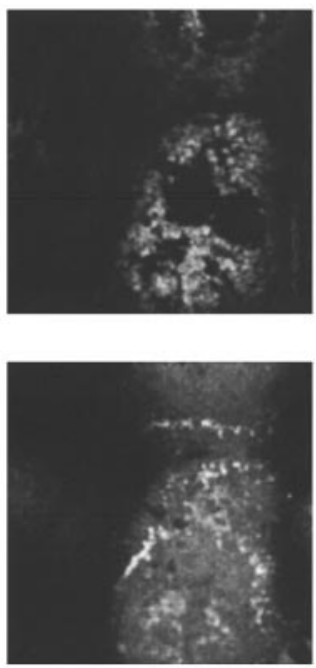

$10 \mu \mathrm{m}$
Figure 7. Jo2 induces the MPT in hepatocytes expressing $1 \kappa B$ superrepressor. Primary mouse hepatocytes were treated with Jo2 (0.5 $\mu \mathrm{g} / \mathrm{mL}$ ) after Ad5/кB infection (30 MOI) and then loaded with $(B)$ calcein (lower panel) to monitor the MPT and (A) TMRM (upper panel) to monitor mitochondrial depolarization. Calcein and TMRM fluorescence were monitored simultaneously over time by confocal microscopy. The images were obtained before (left panel) and 3.5 hours after Jo2 treatment (right panel).

\section{TNF- $\alpha$ or anti-Fas Antibody Alone Induces Moderate Cell Killing in iNOS-null Hepatocytes}

Finally, to investigate the requirement for iNOS in the protection from TNF- $\alpha$ - and Fas-mediated apoptosis, we used iNOS knockout mice. As described above, no iNOS protein was expressed in these hepatocytes (Figure 3B). TNF- $\alpha$ or Jo2 alone did not kill hepatocytes from wild-type mice (Figure 10A). However, in iNOS knockout hepatocytes, TNF- $\alpha$ or Jo2 induced moderate cell killing, of approximately $50 \%$ of the cells, without the I $\mathrm{B}$ superrepressor. NF- $\kappa \mathrm{B}$ binding activity by TNF- $\alpha$ or Jo2 was similar in wild-type and iNOS knockout mice (Figure 10B). These results indicate iNOS provides partial protection from TNF- $\alpha$ - and Fas-mediated apoptosis.

\section{Discussion}

This study was undertaken to determine the protective roles of NF- $\mathrm{\kappa B}$ activation and subsequent induction of iNOS in TNF- $\alpha$ - and Fas-mediated apoptosis. We showed that (1) NF- $\mathrm{B}$ activation mediated by
IKK $\beta$ has a protective role in TNF- $\alpha$ - and Fas-mediated apoptosis; (2) TNF- $\alpha$ or anti-Fas agonistic antibody induces iNOS, which requires NF- $\mathrm{BB}$ activation; (3) NO protects hepatocytes from TNF- $\alpha$ - and Fas-mediated apoptosis via inhibition of Bid, the MPT, cytochrome $c$ release, and caspase- 3 and -8 activation; and (4) iNOS provides partial protection from TNF- $\alpha$ - and Fas-mediated apoptosis.

The IKK complex is composed of at least 3 subunits, IKK $\alpha$, IKK $\beta$, and IKK $\gamma$ (NEMO). ${ }^{42}$ IKK $\alpha$ and IKK $\beta$ are highly similar catalytic subunits, and both are capable of IKB phosphorylation in vitro, whereas IKK $\gamma$ is a regulatory subunit. $7,9,43,44$ Previous biochemical and genetic analyses indicated that disruption of the IKK $\alpha$

\section{Ad5I $\kappa$ B+Jo2+SNAP}

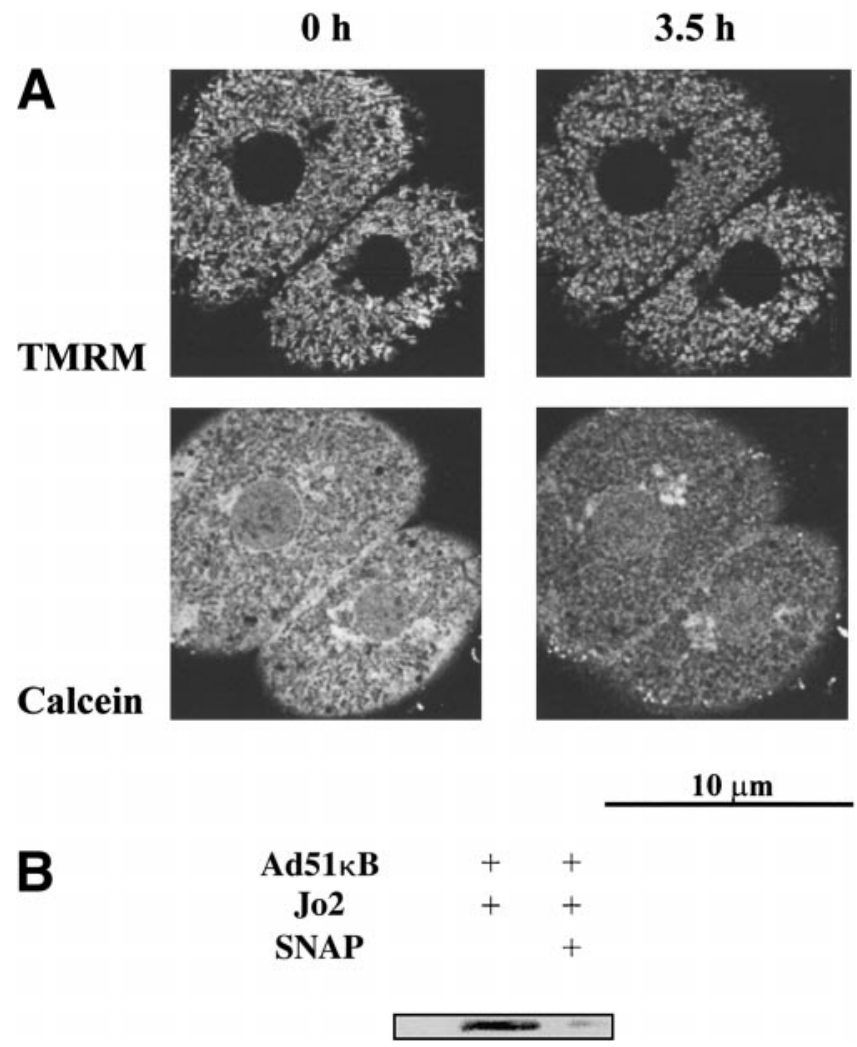

Figure 8. NO donor blocks the MPT and cytochrome $c$ relase induced by Jo2 in hepatocytes expressing $1 \kappa B$ superrepressor. (A) Primary mouse hepatocytes were incubated with Jo2 $(0.5 \mu \mathrm{g} / \mathrm{mL})$ after

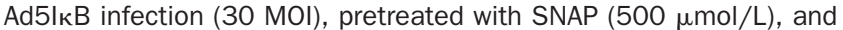
then loaded with calcein (lower panel) to monitor the MPT and TMRM (upper panel) to monitor mitochondrial depolarization. Calcein and TMRM fluorescence were monitored simultaneously over time by confocal microscopy. The images were obtained before (left panel) and 3.5 hours after Jo2 treatment (right panel). (B) The preparation of cytosolic S100-fractions and Western blot analysis for cytochrome $c$ were performed as described previously. ${ }^{33}$ SNAP blocked cytochrome $c$ release from mitochondria by Jo2. 


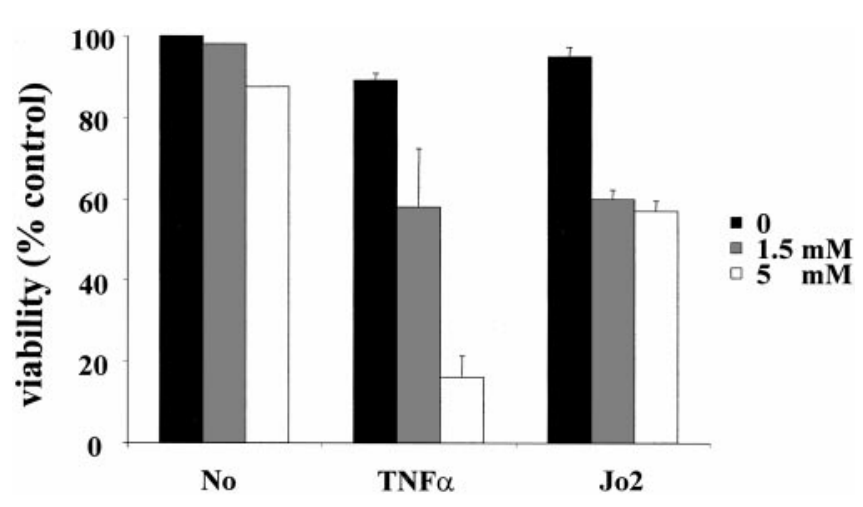

Figure 9. NOS inhibitor, L-NMMA, sensitizes mouse hepatocytes to TNF- $\alpha-$ and Fas-mediated apoptosis. Cell viability was assessed at 17 hours after TNF- $\alpha$ or Jo2 treatment with or without NOS inhibitor, L-NMMA, by a trypan blue exclusion test. Data are shown as average percent viability \pm SEM of 2-4 different experiments.

gene does not abolish activation of IKK by proinflammatory stimuli and resulted in only a small decrease in NF- $\mathrm{BB}$ activation. ${ }^{12}$ IKK $\beta$-deficient mice die at midgestation from uncontrolled liver apoptosis, and IKK $\beta$ knockout fibroblasts have decreased cytokine-induced IKK activity. ${ }^{10,11}$ Consistent with these reports using embryonic fibroblasts, our study showed that TNF- $\alpha$ and Jo2 activate NF-кB through IKKs, especially IKK $\beta$, in adult mouse hepatocytes (Figure 1). Furthermore, NF- $\kappa \mathrm{B}$ activation, mediated by IKK $\beta$, but not IKK $\alpha$, protects primary mouse hepatocytes from TNF- $\alpha-$ or Fas-mediated apoptosis.

A previous study showed that Fas stimulates the DNA binding activity of NF- $\mathrm{KB}$ in a variety of cells, irrespective of their sensitivity or resistance to Fas-mediated cytotoxicity. ${ }^{45}$ Expression of a mutant kinase-deficient NIK blocks NF- $\kappa$ B induction by TNF- $\alpha$ and Fas. ${ }^{4}$ We have previously shown that an adenoviral-mediated expression of the truncated NIK blocks NF- $\kappa$ B binding activity induced by TNF- $\alpha$ or Jo 2 and sensitizes hepatocytes to TNF- $\alpha-$ and Fas-mediated apoptosis in primary mouse hepatocytes. ${ }^{24} \mathrm{In}$ this study, we showed that IKK $\beta$ is critical in NF- $\kappa B$ activation by TNF- $\alpha$ or Jo2 in primary mouse hepatocytes. However, the mechanism by which Jo2 activates NIK and IKK $\beta$ remains elusive. Recent reports showed both Akt and NIK are necessary for TNF activation of NF-кB in 293 cells. Akt mediates IKK $\alpha$ phosphorylation at threonine 23.46 In primary mouse hepatocytes, Jo2 phosphorylated Akt, and constitutively active Akt induced activation of NF- $\kappa$ B (Hatano E and Brenner DA, unpublished data). Therefore, we suggest that Jo2 might have alternative pathways to activate NF- $\kappa B$, whereas TNFR1 interacts with TRADD, TRAF2, and protein kinase receptor interacting protein and activates NIK (or another MAPKKK) and IKK $\beta .^{3-5}$
The molecular regulation of iNOS expression is complex and occurs at multiple levels. ${ }^{30}$ Cytokine mixtures, such as TNF- $\alpha$, IL- $1 \beta$, and IFN- $\gamma$, synergistically activate iNOS expression in the liver. ${ }^{47}$ In previous reports, single cytokines did not induce iNOS, and rat hepatocytes were stimulated with a cytokine mixture including IL-1 $\beta$ and IFN $\gamma$. However, the treatment of TNF- $\alpha$ alone was sufficient to induce iNOS in primary mouse hepatocytes in this study (Figure 3). Interestingly, antiFas antibody Jo2 also induced iNOS mRNA and protein levels, which were blocked by expression of the ІкB superrepressor. This indicates that NF- $\mathrm{BB}$ activation is necessary for iNOS induction. Several previous reports

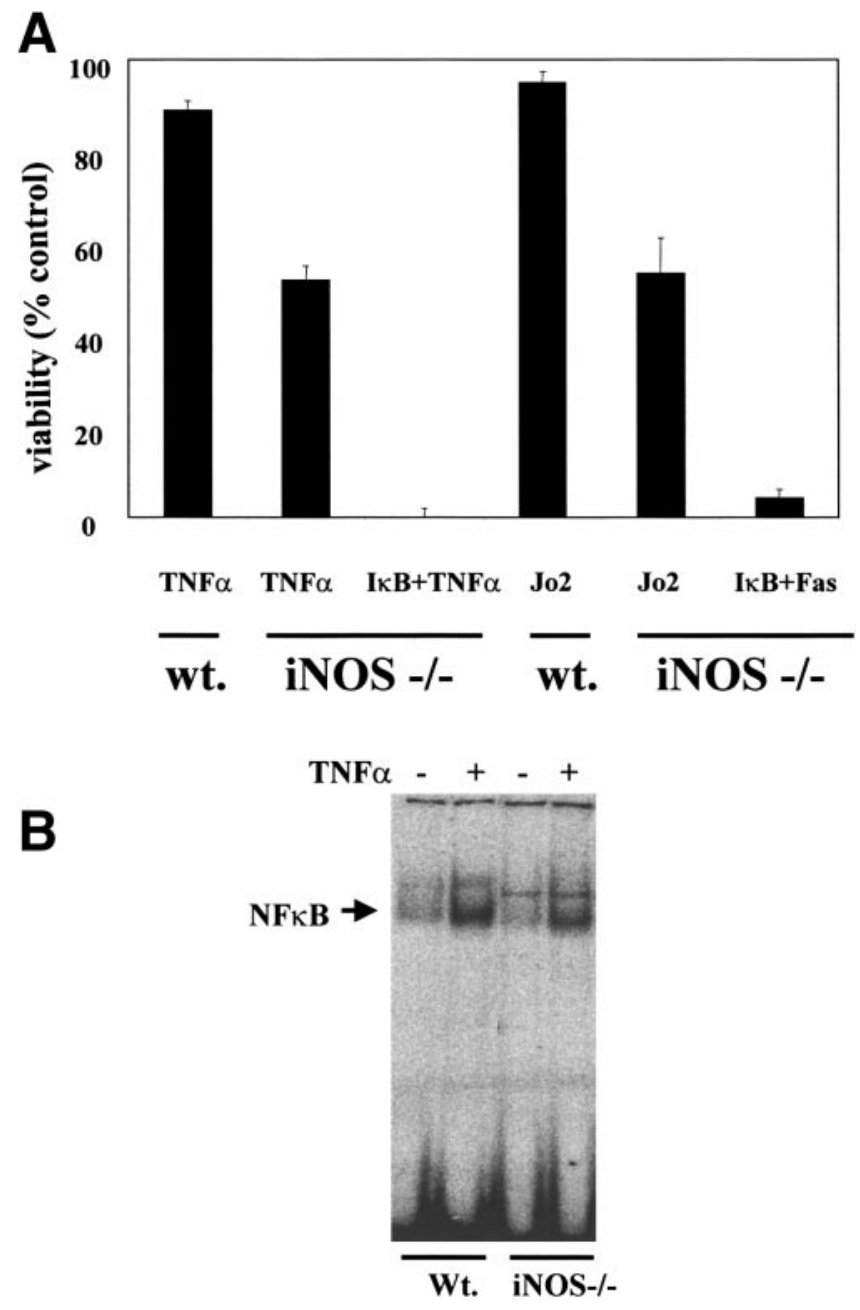

Figure 10. TNF- $\alpha$ or Jo2 induces moderate cell death in $\mathrm{iNOS}^{-} /^{-}$ hepatocytes. (A) Cell viability was assessed at 17 hours after TNF- $\alpha$ or Jo2 treatment in hepatocytes from wild-type (wt) mice or iNOS knockout mice by a trypan blue exclusion test. Data are shown as average percent viability \pm SEM of 2-4 different experiments. (B) NF-kB DNA binding activity was assessed by an electrophoretic mobility shift assay using an NF-kB binding site as the probe with nuclear extracts from hepatocytes from wt mice or iNOS knock-out mice after 30 minutes incubation with TNF- $\alpha$. 
have also shown NF- $\mathrm{KB}$ activation is required for induction of iNOS in other-cell types. ${ }^{48,49}$ However, transcription of iNOS in rat mesangial cells requires additional signals besides activation of NF- $\mathrm{KB} .{ }^{50}$ In skin-derived dendritic cells, JAK2 and p38MAPK are involved in iNOS expression. ${ }^{51}$ Because TNF- $\alpha$ and Jo2 activate p38MAPK in mouse hepatocytes (Hatano $\mathrm{E}$ and Brenner $\mathrm{DA}$, unpublished data), activation of NF- $\mathrm{\kappa B}$ might be necessary but not sufficient for transcription of iNOS.

$\mathrm{NO}$ is known to have both proapoptotic and antiapoptotic effects. iNOS induction might have proapoptotic effects on inhibition of mitochondrial function or the generation of highly toxic peroxynitrite. ${ }^{52}$ Meanwhile, NO may prevent apoptosis in induction of cGMP-dependent kinases and by S-nitrosylation of the catalytic activity of caspases. ${ }^{26,28,36}$ Low basal NOS activity inhibits spontaneous apoptosis in B lymphocytes. ${ }^{53}$ Furthermore, the basal NOS activity in human leukocytes inhibits Fas-induced apoptosis via a cGMP-independent mechanism. ${ }^{54} \mathrm{NO}$ also mediates protection from TNF$\alpha$-mediated apoptosis in endothelial cells and hepatocytes, possibly by heat shock protein induction or caspase inhibition. ${ }^{29,55}$ Hsp 70 was not induced in our study, which generated NO by endogenous iNOS or by low concentrations of SNAP. Cellular susceptibility towards apoptotic signaling pathways can effectively be regulated by low level NO pretreatment. In our study, higher concentration of NO produced by the pretreatment of more than $500 \mu \mathrm{mol} / \mathrm{L}$ of SNAP was cytotoxic to primary mouse hepatocytes, whereas lower concentrations of SNAP were protective from TNF- $\alpha$ - and Fas-mediated apoptosis (Figure $4 C$ ). It has been reported that $\mathrm{NO}$ down-regulates iNOS gene transcription, and that the effect is mediated in part by inhibiting NF- $\mathrm{KB}$ activity. ${ }^{56}$ These results indicate a negative feedback mechanism, whereby the product NO down-regulates iNOS gene expression. Consistent with this report, we showed that SNAP reduced NF- $\kappa B$ binding activity (Figure $4 B$ ). Although NF- $\kappa \mathrm{B}$ is down-regulated by SNAP, SNAP itself protected mouse hepatocytes from TNF- $\alpha-$ and Fas-mediated apoptosis. Furthermore, the study using iNOS knockout mice showed that TNF- $\alpha$ or Jo2 induces moderate cell killing in iNOS knockout hepatocytes without sensitization by IкB superrepressor (Figure 10).

These results indicate NO produced by iNOS is a critical antiapoptotic regulator. Interestingly, iNOS knockout mice have decreased hepatocyte proliferation after partial hepatectomy, providing additional evidence for the key role of iNOS in TNF- $\alpha-$ stimulated hepatocytes. ${ }^{57}$ However, TNF- $\alpha$ - or Fas-induced cell death in iNOS null hepatocytes was moderate, approximately
$50 \%$, compared with cell death by TNF- $\alpha$ or Jo2 in wild-type hepatocytes expressing the IкB superrepressor. Therefore, additional NF- $\mathrm{KB}$ responsive genes must be required for the complete protection from TNF- $\alpha-$ and Fas-mediated apoptosis. Recently, it has been shown that prosurvival Bcl-2 homolog $\mathrm{Bfl}-1 / \mathrm{A} 1$ is a direct transcrip-

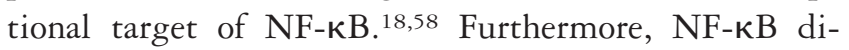
rectly activates the expression of Bcl-xL. ${ }^{59}$ Furthermore, Akt regulates $T$ lymphocyte survival, NF- $\mathrm{KB}$ activation, and Bcl-xL levels. ${ }^{60}$ The roles of these NF- $\mathrm{KB}$ responsive antiapoptotic genes in TNF- $\alpha$ - and Fas-mediated apoptosis in hepatocytes require further study.

NO inhibits the proteolytic cleavage of caspase- 3 (CPP32) into its active subunits, thereby suppressing caspase-3 activity. ${ }^{55}$ In addition, NO potently inhibits apoptosis induction by overexpresssion of Fas associated death domain protein or its immediate downstream target caspase-8. These results suggest that NO modulates the proteolytic cascade upstream of caspase-3. Indeed, NO specifically S-nitrosylates caspase- 8 and caspase- 1 and thereby may prevent activation of the proteolytic cascade. ${ }^{61} \mathrm{~A}$ recent report showed that NO inhibits TRADD recruitment and caspase- 8 activity via a cGMPdependent mechanism in U937 cells and that this effect was overcome by incubation of the cells with exogenous ceramide. ${ }^{62} \mathrm{Bid}$ is a proapoptotic $\mathrm{BH} 3$-only member of the $\mathrm{Bcl}-2$ family, which is proteolytically activated and translocated to the mitochondria to induce cytochrome $c$ release. ${ }^{38-40} \mathrm{Bid}$ is a specific substrate of caspase- 8 in the Fas apoptotic signaling pathway. ${ }^{38}$ We have previously shown that the MPT is a downstream target of caspase8. ${ }^{24,33}$ Furthermore, the MPT is obligatory for TNF- $\alpha-$ induced apoptosis. In Fas-mediated apoptosis, the MPT accelerates the apoptogenic events, but is not obligatory for them. ${ }^{24}$ In the present study, TNF- $\alpha$ and Jo2 caused caspase- 8 activation, Bid cleavage, the MPT, cytochrome $c$ release, and caspase- 3 activation, which were all blocked by pretreatment with SNAP in primary mouse hepatocytes (Figures 5-8). These results indicate that NO blocks targets upstream of the mitochondria, such as caspase- 8 activation. TNF- $\alpha$ - and Fas-mediated apoptosis has been shown to play a major role in the pathogenesis of numerous liver diseases. ${ }^{21,23,63}$ Therefore, NF-кB and/or the NF- $\mathrm{KB}$ responsive gene iNOS may be therapeutic targets for many kinds of liver diseases.

In conclusion, our study shows that both TNF- $\alpha$ and Fas induce iNOS through IKK $\beta$ and subsequent NF- $\mathrm{KB}$ activation to inhibit apoptotic events. However, iNOS induction is not sufficient for complete protection, indicating that additional NF-KB responsive genes have antiapoptotic functions in hepatocytes. 


\section{References}

1. Nagata S, Golstein P. The Fas death factor. Science 1995;267: 1449-1456.

2. Nagata S. Apoptosis by death factor. Cell 1997;88:355-365.

3. Liu ZG, Hsu H, Goeddel DV, Karin M. Dissection of TNF receptor 1 effector functions: JNK activation is not linked to apoptosis while NF-kappaB activation prevents cell death. Cell 1996;87: 565-576.

4. Malinin NL, Boldin MP, Kovalenko AV, Wallach D. MAP3K-related kinase involved in NF-kappaB induction by TNF, CD95 and IL-1. Nature 1997;385:540-544.

5. Natoli G, Costanzo A, Moretti F, Fulco M, Balsano C, Levrero M. Tumor necrosis factor (TNF) receptor 1 signaling downstream of TNF receptor-associated factor 2. Nuclear factor kappaB (NFkap$\mathrm{paB}$ )-inducing kinase requirement for activation of activating protein 1 and NFkappaB but not of C-Jun N-terminal kinase/stressactivated protein kinase. J Biol Chem 1997;272:26079-26082.

6. DiDonato JA, Hayakawa M, Rothwarf DM, Zandi E, Karin M. A cytokine-responsive IkappaB kinase that activates the transcription factor NF-kappaB. Nature 1997;388:548-554.

7. Mercurio F, Zhu H, Murray BW, Shevchenko A, Bennett BL, Li J, Young DB, Barbosa M, Mann M, Manning A, Rao A. IKK-1 and IKK-2: cytokine-activated IkappaB kinases essential for NF-kappaB activation. Science 1997;278:860-866.

8. Woronicz JD, Gao X, Cao Z, Rothe M, Goeddel DV. IkappaB kinase-beta: NF-kappaB activation and complex formation with IkappaB kinase-alpha and NIK. Science 1997;278:866-869.

9. Zandi E, Rothwarf DM, Delhase M, Hayakawa M, Karin M. The IkappaB kinase complex (IKK) contains two kinase subunits, IKKalpha and IKKbeta, necessary for IKappaB phosphorylation and NF-kappaB activation. Cell 1997;91:243-252.

10. Li ZW, Chu W, Hu Y, Delhase M, Deerinck T, Ellisman M, Johnson $\mathrm{R}$, Karin $\mathrm{M}$. The IKKbeta subunit of IkappaB kinase (IKK) is essential for nuclear factor kappaB activation and prevention of apoptosis. J Exp Med 1999;189:1839-1845.

11. Li Q, Van Antwerp D, Mercurio F, Lee KF, Verma IM. Severe liver degeneration in mice lacking the IkappaB kinase 2 gene. Science 1999;284:321-325.

12. Hu $\mathrm{Y}$, Baud V, Delhase $M$, Zhang $P$, Deerinck $T$, Ellisman $M$, Johnson D, Karin M. Abnormal morphogenesis but intact IKK activation in mice lacking the IKKalpha subunit of IkappaB kinase. Science 1999;284:316-320.

13. Van Antwerp DJ, Martin SJ, Kafri T, Green DR, Verma IM. Suppression of TNF-alpha-induced apoptosis by NF-kappaB [see comments]. Science 1996;274:787-789.

14. Wang CY, Mayo MW, Baldwin AS Jr. TNF- and cancer therapyinduced apoptosis: potentiation by inhibition of NF-kappaB. Science 1996;274:784-787.

15. Wang CY, Mayo MW, Korneluk RG, Goeddel DV, Baldwin AS. NF-kappaB antiapoptosis: induction of TRAF1 and TRAF2 and C-IAP1 and C-IAP2 to suppress caspase-8 activation. Science 1998;281:1680-1683.

16. Wu MX, Ao Z, Prasad KV, Wu R, Schlossman SF. IEX-1L, an apoptosis inhibitor involved in NF-kappaB-mediated cell survival. Science 1998;281:998-1001.

17. Duriez PJ, Wong F, Dorovini-Zis K, Shahidi R, Karsan A. A1 functions at the mitochondria to delay endothelial apoptosis in response to tumor necrosis factor. J Biol Chem 2000; 275: 18099-18107.

18. Wang CY, Guttridge DC, Mayo MW, Baldwin AS Jr. NF-kappaB induces expression of the $\mathrm{Bcl}-2$ homologue $\mathrm{A} 1 / \mathrm{Bfl}-1$ to preferentially suppress chemotherapy-induced apoptosis. Mol Cell Biol 1999;19:5923-5929.

19. Sarma V, Lin Z, Clark L, Rust BM, Tewari M, Noelle RJ, Dixit VM. Activation of the B-cell surface receptor CD40 induces A20, a novel zinc finger protein that inhibits apoptosis. J Biol Chem 1995;270:12343-12346.

20. Krammer PH. The CD95(APO-1/Fas)/CD95L system. Toxicol Lett 1998;102,103:131-137.

21. Feldmann G, Lamboley C, Moreau A, Bringuier A. Fas-mediated apoptosis of hepatic cells. Biomed Pharmacother 1998;52:378385.

22. Galle PR, Krammer PH. CD95-induced apoptosis in human liver disease. Semin Liver Dis 1998;18:141-151.

23. Pinkoski MJ, Brunner T, Green DR, Lin T. Fas and Fas ligand in gut and liver. Am J Physiol Gastrointest Liver Physiol 2000;278: G354-G366.

24. Hatano E, Bradham CA, Stark A, limuro Y, Lemaster JJ, Brenner DA. The mitochondrial permeability transition augments Fas-induced apoptosis in mouse hepatocytes. J Biol Chem 2000;275: 11814-11823.

25. Brown GC. Nitric oxide and mitochondrial respiration. Biochem Biophys Acta 1999;1411:351-369.

26. Melino G, Bernassola F, Knight RA, Corasaniti MT, Nistico G, Finazzi-Agro A. S-nitrosylation regulates apoptosis [letter]. Nature 1997;388:432-433.

27. Wang JH, Redmond HP, Wu QD, Bouchier-Hayes D. Nitric oxide mediates hepatocyte injury. Am J Physiol 1998;275:G11171126.

28. Kim YM, Talanian RV, Billiar TR. Nitric oxide inhibits apoptosis by preventing increases in caspase-3-like activity via two distinct mechanisms. J Biol Chem 1997;272:31138-31148.

29. Kim YM, de Vera ME, Watkins SC, Billiar TR. Nitric oxide protects cultured rat hepatocytes from tumor necrosis factor-alpha-induced apoptosis by inducing heat shock protein 70 expression. J Biol Chem 1997;272:1402-1411.

30. Taylor BS, Alarcon LH, Billiar TR. Inducible nitric oxide synthase in the liver: regulation and function. Biochemistry (Mosc) 1998;63: 766-781.

31. Moldeus P, Hogberg J, Orrenius S. Isolation and use of liver cells. Methods Enzymol 1978;52:60-71.

32. Laubach VE, Shesely EG, Smithies O, Sherman PA. Mice lacking inducible nitric oxide synthase are not resistant to lipopolysaccharide-induced death. Proc Natl Acad Sci USA 1995;92:1068810692.

33. Bradham CA, Qian T, Streetz K, Trautwein C, Brenner DA, Lemasters $\mathrm{JJ}$. The mitochondrial permeability transition is required for tumor necrosis factor alpha-mediated apoptosis and cytochrome c release. Mol Cell Biol 1998;18:6353-6364.

34. limuro $\mathrm{Y}$, Nishiura T, Hellerbrand $\mathrm{C}$, Behrns KE, Schoonhoven R, Grisham JW, Brenner DA. NFkappaB prevents apoptosis and liver dysfunction during liver regeneration. J Clin Invest 1998;101: 802-811.

35. Bradham CA, Stachlewitz RF, Gao W, Qien T, Jayadev S, Jenkins G, Hannun Y, Lemasters JJ, Thurman RG, Brenner DA. Reperfusion after liver transplantation in rats differentially activates the mitogen-activated protein kinases. Hepatology 1997;25:11281135.

36. Li J, Bombeck CA, Yang S, Kim YM, Billiar TR. Nitric oxide suppresses apoptosis via interrupting caspase activation and mitochondrial dysfunction in cultured hepatocytes. J Biol Chem 1999;274:17325-17333.

37. Umansky V, Hehner SP, Dumont A, Hofmann TG, Schirrmacher V, Droge W, Schmitz ML. Co-stimulatory effect of nitric oxide on endothelial NF-kappaB implies a physiological self-amplifying mechanism. Eur J Immunol 1998;28:2276-2282.

38. Li H, Zhu H, Xu CJ, Yuan J. Cleavage of BID by caspase 8 mediates the mitochondrial damage in the Fas pathway of apoptosis. Cell 1998;94:491-501.

39. Luo X, Budihardjo I, Zou H, Slaughter C, Wang X. Bid, a Bcl2 interacting protein, mediates cytochrome $c$ release from mito- 
chondria in response to activation of cell surface death receptors. Cell 1998;94:481-490.

40. Yin XM, Wang K, Gross A, Zhao Y, Zinkel S, Klocke B, Roth KA, Korsmeyer SJ. Bid-deficient mice are resistant to Fas-induced hepatocellular apoptosis. Nature 1999;400:886-891.

41. Pastorino JG, Simbula G, Yamamoto K, Glascott PA, Rothman RJ, Farber JL. The cytotoxicity of tumor necrosis factor depends on induction of the mitochondrial permeability transition. J Biol Chem 1996;271:29792-29798.

42. Karin M. How NF-kappaB is activated: the role of the IkappaB kinase (IKK) complex. Oncogene 1999;18:6867-6874.

43. Cohen L, Henzel WJ, Baeuerle PA. IKAP is a scaffold protein of the IkappaB kinase complex. Nature 1998;395:292-296.

44. Rothwarf DM, Zandi E, Natoli G, Karin M. IKK-gamma is an essential regulatory subunit of the IkappaB kinase complex. Nature 1998;395:297-300.

45. Ponton A, Clement MV, Stamenkovic I. The CD95 (APO-1/Fas) receptor activates NF-kappaB independently of its cytotoxic function. J Biol Chem 1996;271:8991-8995.

46. Ozes ON, Mayo LD, Gustin JA, Pfeffer LM, Donner DB. NF-kappaB activation by tumour necrosis factor requires the Akt serinethreonine kinase. Nature 1999;401:82-85.

47. Geller DA, Lowenstein CJ, Shapiro RA, Nussler AK, DiSilvio M, Wang SC, Nakayama DK, Simmons RL, Snyder SH, Billiar TR. Molecular cloning and expression of inducible nitric oxide synthase from human hepatocytes. Proc Natl Acad Sci USA 1993; 90:3491-3495.

48. Diaz-Guerra MJM, Velasco M, Martin-Sanz P, Bosca L. Evidence for common mechanisms in the transcriptional control of type II nitric oxide synthase in isolated hepatocytes. Requirement of NF-kappaB activation after stimulation with bacterial cell wall products and phorbol esters. J Biol Chem 1996;271:3011430120.

49. Diaz-Guerra MJ, Velasco M, Martin-Sanz P, Bosca L. Nuclear factor kappaB is required for the transcriptional control of type II NO synthase in regenerating liver. Biochem J 1997;326:791797.

50. Beck KF, Sterzel RB. Cloning and sequencing of the proximal promoter of the rat iNOS gene: activation of NFkappaB is not sufficient for transcription of the iNOS gene in rat mesangial cells. FEBS Lett 1996;394:263-267.

51. Cruz MT, Duarte CB, Goncalo M, Carvalho AP, Lopes MC. Involvement of JAK2 and MAPK on type II nitric oxide synthase expression in skin-derived dendritic cells. Am J Physiol 1999;277: C1050-1057.

52. Brune B, Sandau K, von Knethen A. Apoptotic cell death and nitric oxide: activating and antagonistic transducing pathways. Biochemistry (Mosc) 1998;63:817-825.

53. Mannick JB, Asano K, Izumi K, Kieff E, Stamler JS. Nitric oxide produced by human B lymphocytes inhibits apoptosis and Epstein-Barr virus reactivation. Cell 1994;79:1137-1146.

54. Mannick JB, Miao XQ, Stamler JS. Nitric oxide inhibits Fas-induced apoptosis. J Biol Chem 1997;272:24125-24128.

55. Dimmeler S, Haendeler J, Nehls M, Zeiher AM. Suppression of apoptosis by nitric oxide via inhibition of interleukin-1beta-converting enzyme (ICE)-like and cysteine protease protein (CPP)-32like proteases. J Exp Med 1997;185:601-607.

56. Taylor BS, Kim YM, Wang Q, Shapiro RA, Billiar TR, Geller DA. Nitric oxide down-regulates hepatocyte-inducible nitric oxide synthase gene expression. Arch Surg 1997;132:1177-1183.

57. Rai RM, Lee FY, Rosen A, Yang SQ, Lin HZ, Koteish A, Liew FY, Zaragoza C, Lowenstein C, Diehl AM. Impaired liver regeneration in inducible nitric oxide synthase deficient mice. Proc Natl Acad Sci USA 1998:95:13829-13834.

58. Zong WX, Edelstein LC, Chen C, Bash J, Gelinas C. The prosurvival $\mathrm{Bcl}-2$ homolog $\mathrm{Bfl}-1 / \mathrm{A} 1$ is a direct transcriptional target of NF-kappaB that blocks TNFalpha-induced apoptosis. Genes Dev 1999;13:382-387.

59. Chen C, Edelstein LC, Gelinas C. The Rel/NF-kappaB family directly activates expression of the apoptosis inhibitor Bcl-x(L). Mol Cell Biol 2000;20:2687-2695.

60. Jones RG, Parsons M, Bonnard M, Chan VS, Yeh WC, Woodgett $J R$, Ohashi PS. Protein kinase B regulates T lymphocyte survival, nuclear factor kappaB activation, and bcl-X(L) levels in vivo. J Exp Med 2000;191:1721-1734.

61. Dimmeler S, Haendeler J, Sause A, Zeiher AM. Nitric oxide inhibits APO-1/Fas-mediated cell death. Cell Growth Differ 1998;9: 415-422.

62. De Nadai C, Sestili P, Cantoni O, Lievremont JP, Sciorati C, Barasacchi R, Moncada S, Meldolesi J, Clementi E. Nitric oxide inhibits tumor necrosis factor-alpha-induced apoptosis by reducing the generation of ceramide. Proc Natl Acad Sci USA 2000; 97:5480-5485.

63. Bradham CA, Plumpe J, Manns MP, Brenner DA, Trautwein C. Mechanisms of hepatic toxicity. I. TNF-induced liver injury. Am J Physiol 1998;275:G387-392.

Received August 26, 2000. Accepted December 6, 2000.

Address requests for reprints to: David A. Brenner, M.D., C.B. 7080, University of North Carolina at Chapel Hill, Chapel Hill, North Carolina 27599. e-mail: dab@med.unc.edu; fax: (919) 966-7468.

Supported by Research Fellowships of the Japan Society for the Promotion of Science for Young Scientists (to E.H.), and National Institutes of Health Grants GM41804 (to D.A.B.), DK34987 (to D.A.B. and J.J.L.), AA11605 (to D.A.B. and J.J.L.), DK37034 (to J.J.L.), and AG07218 (to J.J.L.). 